\title{
Management of the Thalassemias
}

\author{
Nancy F. Olivieri ${ }^{1}$ and Gary M. Brittenham ${ }^{2}$ \\ ${ }^{1}$ Hemoglobinopathy Research University Health Network, Toronto, Ontario M5G 2C4, Canada \\ ${ }^{2}$ Department of Pediatrics, Columbia University, New York, New York 10032 \\ Correspondence: gmb31@columbia.edu
}

During the last 30 years, in addition to the considerable progress made in control and prevention of thalassemias ${ }^{3}$, there have also been major advances in their symptomatic management, at least in wealthier countries where appropriate facilities are available. Remarkable improvements in survival in the severe forms of thalassemia have followed the more judicious use of blood transfusion and, in particular, the ability to manage the iron accumulation resulting from transfusion with its severe and ultimately lethal effects on endocrine and cardiac function.

$\mathrm{B}_{\mathrm{i}}^{\mathrm{e}}$ ecause the management of severe and milder intermittent forms of $\beta$ - and $\alpha$-thalassemia have been described in detail recently (Weatherall and Clegg 2001; Higgs 2009; Olivieri and Weatherall 2009; Taher et al. 2011, 2012), after a short introduction to the general principles of management of these conditions, this article focuses on the control of iron overload in the different forms of thalassemia.

\section{GENERAL PRINCIPLES OF THE MANAGEMENT OF THALASSEMIAS}

Although the more severe thalassemias are an extremely heterogeneous group of disorders, their general management follows the same principles. At first presentation, it is absolutely essential to obtain an accurate diagnosis of the form of the disease, ideally including its molecular basis. It is also important to perform a detailed family study to assess the pattern of inheritance at the same time. Once this information is available, the family requires well-informed counseling about the likely future course of the illness and, equally important, about the relative risks of having further affected children.

It is not uncommon for babies to first present with thalassemia with particularly low hemoglobin levels associated with intercurrent infection. Although they may need to receive transfusions until they recover from the presenting illness, it is important not to establish them on regular transfusion without a reasonable period of observation. Unless this precaution is taken, babies with various forms of thalassemia of intermediate severity may be placed on lifelong unnecessary transfusion. The important features to observe before long-term transfusion is considered include the patterns of growth and growth velocity, activity compared with infants of the same age, the occurrence of progressive splenomegaly, and early evidence of any skeletal

\footnotetext{
${ }^{3}$ See Cao and Kan (2013).

Editors: David Weatherall, Alan N. Schechter, and David G. Nathan

Additional Perspectives on Hemoglobin and Its Diseases available at www.perspectivesinmedicine.org

Copyright (C) 2013 Cold Spring Harbor Laboratory Press; all rights reserved; doi: 10.1101/cshperspect.a011767

Cite this article as Cold Spring Harb Perspect Med 2013;3:a011601
} 
deformity. Although the hemoglobin level is also important, it should not be the only determinant of whether transfusion is required. In some forms of $\beta$-thalassemia intermedia, notably $\mathrm{HbE} \beta$-thalassemia in particular, there is increasing evidence that patients may be able to adapt to relatively low hemoglobin levels and not require regular transfusion (Allen et al. 2010).

During later stages of development, these children-as well as continuing to be assessed regarding their growth, skeletal status, and spleen size-also need regular assessment of their hematologic findings together with their bone age, liver, endocrine and cardiac functions, as well as their iron status, which is considered in detail below.

Ideally, these patients should be managed in special centers with expertise in the management of thalassemia and with access to pediatricians in a variety of related specialties. Because so many of these patients now survive for much longer periods of time, it is also vital that these centers have staff with special knowledge of the manifestations of the thalassemias in adults, again with the appropriate specialist facilities in related fields.

Recent developments in more radical forms of treatment for the thalassemias-notably bone marrow transplantation, gene therapy, and stem cell therapy—have been reviewed elsewhere ( $\mathrm{Da}$ ley 2012; Lucarelli and Tisdale 2012; Nienhuis and Persons 2012).

\section{IRON ACCUMULATION IN THALASSEMIA}

Thalassemia patients who are not transfused may retain up to $75 \%$ of orally administered iron, accumulating between 3 and $9 \mathrm{mg}$ of iron per day (Pippard et al. 1979). Because transfusions suppress erythroid expansion and reduce ineffective erythropoiesis, thereby reducing iron absorption (Pippard and Weatherall 1984), the goal of regular transfusions in thalassemia is to ameliorate these processes and correct anemia. The judicious application of a transfusion regimen in which pretransfusion hemoglobin concentrations do not exceed 9.5 $\mathrm{g} / \mathrm{dL}$ achieves an optimal balance between accu- mulation of body iron and suppression of eryrthroid marrow activity (Cazzola et al. 1997). These regimens administer 100-200 mL RBCs/ $\mathrm{kg}$ per year (Porter 2001). Transfusion requirements may be influenced by the severity of globin chain imbalance and by splenectomy, among other factors (Rebulla and Modell 1991), and daily accumulation of iron may therefore vary between 0.30 and $0.59 \mathrm{mg} / \mathrm{kg}$ (Cohen et al. 2008).

\section{ASSESSMENT OF IRON IN VIVO}

\section{Serum Ferritin Concentration}

Concentrations of plasma or serum ferritin, commonly used to estimate body iron, derive from ferritin synthesis as well as its release from damaged cells. If serum ferritin concentration exceeds $4000 \mu \mathrm{g} / \mathrm{L}$, suggested as an upper physiological limit of the rate of synthesis, higher concentrations are believed to be due to the release of ferritin from damaged cells (Prieto et al. 1975; Worwood et al. 1980). Interpretation of values may be complicated by a variety of conditions, all common in thalassemia, that alter concentrations independently of changes in body iron burden, including ascorbate deficiency, fever, acute infection, chronic inflammation, acute and chronic hepatic damage, hemolysis, and ineffective erythropoiesis (Olivieri and Brittenham 1997). The $95 \%$ prediction intervals for hepatic iron concentration, given the plasma ferritin, are too broad to make the determination of ferritin a reliable predictor of body iron stores (Brittenham et al. 1993). A retrospective analysis in deferoxamine-treated patients found that during a period of 15 years, maintenance of serum ferritins of $2500 \mu \mathrm{g} / \mathrm{L}$ was associated with estimates of improved cardiac-disease-free survival (Olivieri et al. 1994). These findings were confirmed in subsequent studies, with lower ferritin concentration reported to predict even longer survivals (Telfer et al. 2000; Borgna-Pignatti et al. 2004a; Davis et al. 2004). These findings should not be interpreted to suggest, in the day-to-day management of individual patients, that serum ferritin is an accurate assessment of body iron burden, 
although in clinical practice serum ferritin continues to be measured, usually at 6-mo intervals. Documentation of changes may be useful to encourage patients and clinicians in compliance with treatment (Davis and Porter 2000) and, as described further below, regular measurements may also be useful in monitoring the risk of deferoxamine toxicity, especially in children (Porter and Davis 2002).

\section{Liver Iron Concentration}

The liver is the major repository of transfused iron. Hepatic parenchymal iron accumulation may rapidly progress to portal fibrosis in a significant percentage of patients, including children (Iancu and Neustein 1977). In thalassemia major, progressive liver disease itself is an important cause of death in young adults (Zurlo et al. 1989) and represents a risk factor for hepatocellular carcinoma (Borgna-Pignatti et al. 2004b).

The uncertainties with respect to serum ferritin concentration have led to recommendations for the application of quantitative measurements of body iron, especially in studies to evaluate the effectiveness of new chelating agents. Liver iron correlates closely with total body iron. In patients with transfusion-dependent thalassemia, the concentration of total body iron (in milligrams per kilogram of body weight) is equivalent to 10.6 times the hepatic iron concentration (in milligrams per gram of liver, dry weight $[\mathrm{dw}])$. Using this equation, it is possible to reliably estimate total body iron stores that reach as high as $250 \mathrm{mg} / \mathrm{kg}$ of body weight, with a standard error of $<7.9$ (Angelucci et al. 2000). Elevated levels of liver iron are useful in predicting the risk of complications of iron loading in vivo (Brittenham 2011). Historically, assessment of liver iron was determined through biopsies of the liver but now generally relies largely on magnetic resonance imaging (MRI) exploiting the paramagnetic effects of tissue iron on surrounding tissues, which alters the relaxation time of molecules excited by application of a magnetic field (Porter and Shah 2010). One MRI method (R2; Ferriscan) that uses widely available equipment has been stan- dardized and validated to be predictive over a clinically useful range of liver iron concentrations (St Pierre et al. 2005).

\section{Assessment of Cardiac Iron}

Even in transfused, nonchelated patients with thalassemia, cardiac disease related to iron overload does not usually develop during the second decade of life. As more extensively outlined below, this complication has become rare in patients in whom deferoxamine therapy is available and who are managed by attentive medical personnel.

Cardiovascular T2-star $\left(\mathrm{T}^{*}\right)$ magnetic resonance (CMR T2 ${ }^{*}$ ) has been used to guide ironchelating therapy (Anderson et al. 2001), but calibrated methods are not available for all patients (Brittenham 2011). Early, short-term cross-sectional studies involving CMR T2* (Anderson et al. 2002, 2006) suggested poor correlations between CMR T2* and liver iron (as well as serum ferritin) concentrations and proposed that CMR T2* measurements were superior to serial determinations of liver iron in the evaluation of responses to iron-chelating therapy. These conclusions have been challenged by the identification of a calibration error in $\mathrm{T} 2 *$ liver measurements conducted by the London investigators, leading in many studies to repeated underestimation of liver iron concentration (Pennell et al. 2006; Tanner et al. 2008). Even if iron within the heart is correctly imaged (Garbowski et al. 2008), simple cross-sectional associations between the two organs may have limited usefulness because of delays in loading and removal of cardiac iron, relative to these processes in the liver (Noetzli et al. 2008). The influences on CMR T2* of the rate of tissue iron loading, the age at the start of iron loading, the processes of iron absorption and ineffective erythropoiesis, and the particular iron-chelating therapy administered remain poorly understood. The clinical significance of measurements of CMR T2* was further questioned by a recent U.S. Food and Drug Administration inspection of a trial (Pennell et al.2006) using this modality to evaluate the relative effectiveness of two iron-chelating therapies (Food and Drug Administration 2011). 
In summary, no robust data appear to effectively contradict the long-established association of liver iron concentration and the risk of development of complications in thalassemia. Body iron burdens corresponding to hepatic iron concentrations exceeding $\sim 15-20 \mathrm{mg}$ iron/g liver, dw have been shown to place patients at heightened risk of cardiac disease and early death (Brittenham et al. 1994; Telfer et al. 2000), liver dysfunction (Jensen et al. 2003), and acceleration of hepatic portal fibrosis (Angelucci et al. 2002). Lack of certainty exists with respect to optimal hepatic iron concentrations that minimize the risk that hepatic fibrosis will progress to cirrhosis and its ultimate complication, hepatocellular carcinoma (Borgna-Pignatti et al. 2004a,b; Ko et al. 2007).

It is also of clinical relevance that the development of cardiac disease may be predicted from a liver iron concentration obtained as much as 13 years previously (Telfer et al. 2000). This suggests that measurements of liver iron may provide an opportunity to optimize therapy, before organ dysfunction develops, that is more extended than reportedly provided by measurements of CMR T2* (Kirk et al. 2009).

\section{Extrahepatic Iron}

The most common clinical problem in transfused patients with thalassemia is hypogonadotropic hypogonadism (Porter and Shah 2010), related to selective iron deposition in pituitary gonadotropes (Bergeron and Kovacs 1978) as body iron burden increases (Musallam et al. 2011). Following early studies observing that anterior pituitary iron imaged by magnetic resonance (Fujisawa et al. 1988) could be correlated with biochemical markers of hypogonadism (Chatterjee et al. 1998), techniques to image the anterior pituitary have improved (Argyropoulou et al. 2003; Christoforidis et al. 2007; Au et al. 2008b; Noetzli et al. 2011b) but are not widely used in clinical practice. Diabetes mellitus, attributed to several processes including insulin resistance as well as chronic pancreatic iron overload, is also a frequently observed complication in patients in whom body iron burden is poorly controlled (Olivieri and Brittenham
1997). During the last decade, there has been progress in the MRI of pancreatic iron (Midiri et al. 1999; Au et al. 2008a,b; Noetzli et al. 2009, 2011a); correlation of pancreatic MRI parameters with tests of pancreatic function is still awaited.

\section{Nontransferrin-Bound Iron}

In thalassemia, after plasma iron exceeds the transport capacity of circulating transferrin, a fraction of iron known as nontransferrin-bound iron (NTBI) appears in plasma. NTBI comprises a heterogeneous assortment of iron complexes that are believed to be the major mediators of extrahepatic tissue damage in transfusional iron overload (Breuer et al. 2000). NTBI enters hepatocytes, cardiomyocytes, anterior pituitary cells, and pancreatic $\beta$ cells, leading to the generation of reactive oxygen species. Damage to lipids, proteins, DNA, and subcellular organelles may result in cellular dysfunction, apoptosis, and necrosis (Brittenham 2011). In addition to removing excess iron from cells, chelating therapy agents may reduce NTBI, but in clinical practice measurements they are not generally used to assess the response to therapy (Jacobs et al. 2005).

\section{Other Means of Assessing Iron Loading}

Serum iron, transferrin, transferrin saturation, transferrin receptor concentration, and urinary iron excretion do not quantitatively reflect body iron stores. A study of the iron-chelating agent deferasirox based the initial dose on a calculated rate of transfusional iron loading and then adjusted the dose according to measurements of serum ferritin levels and safety markers over a 1yr period (Cappellini et al. 2010). As noted, the long-term efficacy and safety of this strategy are uncertain (Brittenham 2011).

\section{CHELATION IN CLINICAL PRACTICE}

Iron-chelating therapy should be considered in all patients with thalassemia who require longterm red-cell transfusion. Chelators should be avoided in patients who are pregnant or breastfeeding. Ideally, therapy should be initiated 
prophylactically, before clinically significant iron accumulation has occurred. Patients who have already undergone repeated transfusion without sufficient chelation can also be successfully treated, but they may require intensive regimens (Brittenham 2011).

\section{Initiation of Iron-Chelating Therapy}

A study in children with thalassemia major found that liver iron may exceed $7 \mathrm{mg} / \mathrm{g} \mathrm{dw}$ between the 10th and 20th transfusion (Saxon et al. 1997). Before initiation (and any adjustment) of iron-chelating therapy, detailed documentation of the history of transfusion, previous iron-chelating therapy, if any, estimation of the rate of transfusional iron loading, and determination of the body iron load by measurement of the hepatic iron concentration should be undertaken. In clinical practice, body iron is also estimated regularly by serum ferritin concentration. The extent of any existing iron-induced hepatic, cardiac, or endocrine dysfunction should be established. In children and adolescents, height and weight velocity and percentiles and stage of sexual maturation should be documented. Pretherapy toxicity evaluations should be tailored to the chelating agent to be implemented, as detailed below.

The dose of an iron-chelating agent is determined by the presence or absence of cardiac iron overload, the rate of transfusional iron loading, and the body iron burden. In the absence of cardiac iron overload, the long-term objective is to maintain body iron at a level that permits safe storage while avoiding chelator toxicity. The greater the rate of transfusional iron loading, the greater the dose of an iron chelator that will be needed to control the accumulation of iron (as outlined in Table 1 [adapted from Brittenham 2011]).

\section{Monitoring of Effectiveness}

The toxic manifestations of iron depend not only on tissue concentrations but also the rate of accumulation, duration of exposure to increased iron, ascorbate status (which helps to determine the allocation of iron between mac- rophage and parenchymal cells), extent of internal redistribution of iron between macrophage and parenchymal sites, and noniron-related factors, such as alcohol and viral hepatitis (Olivieri and Brittenham 1997). If cardiac iron overload is present, eliminating excess iron from the heart becomes the primary therapeutic goal (see Table 1). Because chelators remove iron from the heart much more slowly than from the liver, prolonged, intensive iron-chelating therapy is usually needed. As a result, in chelated patients, the presence of cardiac iron cannot be predicted from the liver iron concentration. Iron-chelating therapy may have reduced the liver iron to an optimal range despite the persistence of severe cardiac iron overload. Nevertheless, cardiac iron loading can be prospectively predicted in the presence of sustained severe iron overload with elevated hepatic iron concentrations (Noetzli et al. 2008).

In the absence of cardiac iron overload, the primary therapeutic goal then becomes maintenance of the body iron burden at a level that permits safe storage while avoiding chelator toxicity from administering excessive amounts relative to the body iron. The best measure of the body iron load is the hepatic storage iron concentration, which reflects iron accumulations in both hepatocytes and reticuloendothelial macrophages (Kupffer cells). Therapy to maintain body iron at levels found in healthy, never-transfused individuals, corresponding to a hepatic iron of $\sim 0.2-1.6 \mathrm{mg}$ iron/g liver, $\mathrm{dw}$ (Brittenham et al. 1982) may increase the probability of dose-related chelator toxicity. At the opposite extreme, body iron burdens corresponding to hepatic iron concentrations exceeding $\sim 15-$ $20 \mathrm{mg}$ iron/g liver, dw place patients at risk of serious complications of iron loading (Brittenham et al. 1994; Telfer et al. 2000; Angelucci et al. 2002; Jensen et al. 2003). In transfusion-dependent patients with thalassemia, hepatic iron concentrations of $\sim 3-7 \mathrm{mg} / \mathrm{g}$ of liver, dw are generally regarded as optimal, seeming to minimize the risks both of adverse drug effects and complications from iron overload. The safety and long-term effectiveness of off-label regimens of therapy during which body storage iron is reportedly normalized (Farmaki et al. 


\begin{tabular}{|c|c|c|c|c|c|}
\hline \multirow[b]{2}{*}{$\begin{array}{l}\text { Hepatic iron } \\
\text { concentration } \\
\end{array}$} & \multicolumn{3}{|c|}{ No cardiac iron overload $\left(\mathrm{T}_{2}{ }^{*}, \geq 20 \mathrm{msec}\right)$; daily transfusional iron intake } & \multicolumn{2}{|c|}{ Cardiac iron overload $\left(\mathrm{T}_{2}{ }^{*},<20 \mathrm{msec}\right)$} \\
\hline & $\begin{array}{c}<0.3 \mathrm{mg} / \mathrm{kg} \text { of body } \\
\text { weight }\end{array}$ & $\begin{array}{c}0.3-0.5 \mathrm{mg} / \mathrm{kg} \text { of body } \\
\text { weight }\end{array}$ & $\begin{array}{c}>0.5 \mathrm{mg} / \mathrm{kg} \text { of body } \\
\text { weight }\end{array}$ & $\begin{array}{c}\text { Mild to moderate } \\
\mathrm{T}_{2}{ }^{*}, 10 \text { to }<20 \mathrm{msec} \\
\end{array}$ & $\begin{array}{c}\text { Severe } \\
\mathrm{T}_{2}^{*},<10 \mathrm{msec} \\
\end{array}$ \\
\hline$\geq 15 \mathrm{mg} / \mathrm{g}, \mathrm{dw}$ & $\begin{array}{l}\text { Deferoxamin: } 40-50 \mathrm{mg} / \\
\mathrm{kg} / \mathrm{d}, 8-10 \mathrm{~h} / \mathrm{d}, 6 \text { or } 7 \mathrm{~d} / \\
\text { wk, by subcutaneous } \\
\text { infusion; deferasirox: } \\
\text { infusion, deferasirox: oral } \\
\text { dose of } 30-40 \mathrm{mg} / \mathrm{kg} \\
\text { daily }\end{array}$ & $\begin{array}{l}\text { Deferoxamine: } 40- \\
50 \mathrm{mg} / \mathrm{kg} / \mathrm{d}, 8-10 \mathrm{~h} / \\
\mathrm{d}, 6 \text { or } 7 \mathrm{~d} / \mathrm{wk} \text { by } \\
\text { subcutaneous infusion; } \\
\text { deferasirox: oral dose of } \\
30-40 \mathrm{mg} / \mathrm{kg} \text { daily }\end{array}$ & $\begin{array}{l}\text { Deferoxamine: } 40- \\
50 \mathrm{mg} / \mathrm{kg} / \mathrm{d}, 8-10 \mathrm{~h} / \\
\mathrm{d}, 6 \text { or } 7 \mathrm{~d} / \text { wk by } \\
\text { subcutaneous infusion; } \\
\text { deferasirox: oral dose of } \\
30-40 \mathrm{mg} / \mathrm{kg} \text { daily }\end{array}$ & $\begin{array}{l}\text { Deferoxamine: } 50 \mathrm{mg} / \mathrm{kg} / \mathrm{d} \\
\text { by continuous intravenous } \\
\text { infusion; deferasirox: oral } \\
\text { dose of } 40 \mathrm{mg} / \mathrm{kg} \text { daily, but } \\
\text { uncertain efficacy in } \\
\text { reducing cardiac iron }\end{array}$ & $\begin{array}{l}\text { Deferoxamine: } 50 \mathrm{mg} / \mathrm{kg} / \\
\text { day by continuous } \\
\text { intravenous infusion, } \\
\text { deferasirox: oral dose of } \\
40 \mathrm{mg} / \mathrm{kg} \text { daily, but } \\
\text { uncertain efficacy in } \\
\text { reducing cardiac iron }\end{array}$ \\
\hline $\begin{array}{l}7 \text { to } 15 \mathrm{mg} / \mathrm{g} \\
\mathrm{dw}\end{array}$ & $\begin{array}{l}\text { Deferoxamine: } 30-40 \mathrm{mg} / \\
\mathrm{kg} / \mathrm{d}, 8-10 \mathrm{~h} / \mathrm{d}, 5 \mathrm{~d} / \mathrm{wk} \\
\text { by subcutaneous } \\
\text { infusion; deferasirox: oral } \\
\text { dose of } 20-30 \mathrm{mg} / \mathrm{kg} \\
\text { daily }\end{array}$ & $\begin{array}{l}\text { Deferoxamine: } 40- \\
50 \mathrm{mg} / \mathrm{kg} / \mathrm{d}, 8-10 \mathrm{~h} / \\
\mathrm{d}, 6 \text { or } 7 \mathrm{~d} / \mathrm{wk} \text { by } \\
\text { subcutaneous infusion; } \\
\text { deferasirox: oral dose of } \\
30-40 \mathrm{mg} / \mathrm{kg} \text { daily }\end{array}$ & $\begin{array}{l}\text { Deferoxamine } 40- \\
50 \mathrm{mg} / \mathrm{kg} / \mathrm{d}, 8-10 \mathrm{~h} / \\
\mathrm{d}, 6 \text { or } 7 \mathrm{~d} / \mathrm{wk} \text { by } \\
\text { subcutaneous infusion; } \\
\text { deferasirox: oral dose of } \\
30-40 \mathrm{mg} / \mathrm{kg} \text { daily }\end{array}$ & $\begin{array}{l}\text { Deferoxamine: } 40-50 \mathrm{mg} / \\
\mathrm{kg} / \mathrm{d}, 8-10 \mathrm{~h} / \mathrm{d}, 6 \text { or } 7 \mathrm{~d} / \\
\text { wk by subcutaneous } \\
\text { infusion; deferasirox: oral } \\
\text { dose of } 30-40 \mathrm{mg} / \mathrm{kg} \text { daily }\end{array}$ & $\begin{array}{l}\text { Deferoxamine: } 40-50 \mathrm{mg} / \\
\mathrm{kg} / \mathrm{d} \text { by continuous } \\
\text { infusion; deferasirox: } \\
\text { oral dose of } 30-40 \mathrm{mg} / \mathrm{kg} \\
\text { daily }\end{array}$ \\
\hline $\begin{array}{l}3 \text { to }<7 \mathrm{mg} / \mathrm{g} \\
\mathrm{dw}\end{array}$ & $\begin{array}{l}\text { Deferoxamine: } 30-40 \mathrm{mg} / \\
\mathrm{kg} / \mathrm{d}, 8-10 \mathrm{~h} / \mathrm{d}, 5 \mathrm{~d} / \mathrm{wk} \text {, } \\
\text { by subcutaneous } \\
\text { infusion; deferasirox: oral } \\
\text { dose of } 20-30 \mathrm{mg} / \mathrm{kg}\end{array}$ & $\begin{array}{l}\text { Deferoxamine: } 30- \\
40 \mathrm{mg} / \mathrm{kg} / \mathrm{d}, 8-10 \mathrm{~h} / \\
\mathrm{d}, 5 \mathrm{~d} / \mathrm{wk} \text {, by } \\
\text { subcutaneous infusion; } \\
\text { deferasirox: oral dose of } \\
20-30 \mathrm{mg} / \mathrm{kg} \text { daily }\end{array}$ & $\begin{array}{l}\text { Deferoxamine: } 30- \\
40 \mathrm{mg} / \mathrm{kg} / \mathrm{d}, 8-10 \mathrm{~h} / \\
\mathrm{d}, 5 \mathrm{~d} / \mathrm{wk} \text { by } \\
\text { subcutaneous infusion: } \\
\text { deferasirox: oral dose of } \\
20-30 \mathrm{mg} / \mathrm{kg}\end{array}$ & $\begin{array}{l}\text { Deferoxamine: } 40-50 \mathrm{mg} / \\
\mathrm{kg} / \mathrm{d}, 8-10 \mathrm{~h} / \mathrm{d}, 6 \text { or } 7 \mathrm{~d} / \\
\text { wk, by subcutaneous } \\
\text { infusion; deferasirox: oral } \\
\text { dose of } 30-40 \mathrm{mg} / \mathrm{kg} \text { daily }\end{array}$ & $\begin{array}{l}\text { Deferoxamine: } 40-50 \mathrm{mg} / \\
\mathrm{kg} / \mathrm{d} \text { by continuous } \\
\text { infusion; deferasirox: oral } \\
\text { dose of } 30-40 \mathrm{mg} / \mathrm{kg} \text { daily }\end{array}$ \\
\hline$<3 \mathrm{mg} / \mathrm{g}, \mathrm{dw}$ & $\begin{array}{l}\text { Deferoxamine: suspend } \\
\text { therapy; deferasirox: } \\
\text { suspend therapy }\end{array}$ & $\begin{array}{l}\text { Deferoxamine: suspend } \\
\text { therapy; deferasirox: } \\
\text { suspend therapy }\end{array}$ & $\begin{array}{l}\text { Deferoxamine: suspend } \\
\text { therapy; deferasirox: } \\
\text { suspend therapy }\end{array}$ & $\begin{array}{l}\text { Deferoxamine: adjust } \\
\text { intravenous or } \\
\text { subcutaneous dose } \\
\text { according to therapeutic } \\
\text { index 32; deferasirox: } \\
\text { adjust oral dose, } \\
\text { monitoring renal and } \\
\text { hepatic function and blood } \\
\text { count }\end{array}$ & $\begin{array}{l}\text { Deferoxamine: adjust } \\
\text { intravenous or } \\
\text { subcutaneous dose } \\
\text { according to therapeutic } \\
\text { index 32; deferasirox adjust } \\
\text { oral dose, monitoring renal } \\
\text { and hepatic function and } \\
\text { blood count }\end{array}$ \\
\hline
\end{tabular}

The dose of deferoxamine in young children should not exceed $25-30 \mathrm{mg} / \mathrm{kg}$ of body weight. The dose should be adjusted according to the therapeutic index (Pennell et al. 2006). The bioavailability may affect the response. $\mathrm{T}_{2}{ }^{*}$, Cardiac transverse relaxation time on magnetic resonance imaging; dw, dry weight. 
2010) await confirmation. Patients with higher body iron burdens exceeding 7 up to $\sim 15 \mathrm{mg}$ iron/g liver, dw are at an increased risk of hepatic fibrosis, diabetes mellitus, and other complications and need more intensive iron-chelation therapy (Angelucci et al. 2000). Patients with still higher body iron burdens, recognized as having a greatly increased risk of early death, are candidates for special programs of management (Brittenham 2011).

In principle, the ineffectiveness of any drug may be related to dose prescribed, adherence to treatment, blood transfusion rate, variability in absorption, metabolism of the drug, or a combination of these and other factors. Administration of a chelator will be needed as long as transfusion is continued and will be lifelong in most patients; effectiveness needs to be sustained over time. But how is effectiveness defined?

Robust criteria to evaluate the effectiveness of iron-chelating therapy are derived from published results of prospective studies of patients with iron overload (Cartwright et al. 1979; Brittenham et al. 1982, 1994; Olivieri et al. 1995) and are based on the ability of the chelator to reduce and maintain body iron at levels associated with favorable clinical outcomes. These criteria should be applied to the clinical evaluation of patients, including in clinical trials of new agents. In brief, a chelating agent is judged to be effective if it reduces or maintains body iron, assessed by hepatic iron concentration, to concentrations associated with prolonged survival free of the complications of iron overload (hepatic iron $3.2-7.0 \mathrm{mg} / \mathrm{g}$ liver, $\mathrm{dw}$ ). A chelating agent is judged to be ineffective if the body iron increases to or is maintained at levels associated with increased risk of the complications of iron overload (hepatic iron $7.1-14.9 \mathrm{mg} / \mathrm{g}$ liver, dw), including those of cardiac disease and premature death (hepatic iron $\geq 15.0 \mathrm{mg} /$ $\mathrm{g}$ liver, dw).

Criteria that refer to "percentage changes" or "improving trends" from baseline hepatic iron may be fundamentally misleading in the interpretation of the effectiveness of an ironchelating agent and may give rise to risks to individual patients. This is illustrated by contrasting the use of two criteria of effectiveness in two patients. Consider first a patient whose initial hepatic iron is $4 \mathrm{mg} / \mathrm{g}$ liver, $\mathrm{dw}$ and, after treatment with an iron-chelating agent, is shown to have hepatic iron of $6 \mathrm{mg} / \mathrm{g}$ liver, dw. Although the hepatic iron has increased by $30 \%$, application of the criteria based on the reduction or maintenance of body iron at levels associated with favorable clinical outcomes would judge the chelator to be effective; the body iron has been maintained within optimal range. In contrast, the application of the criteria using "percentage changes" or "improving trends" would describe this therapy as ineffective. Next, consider another patient in whom initial hepatic iron was $40 \mathrm{mg} / \mathrm{g}$ liver, $\mathrm{dw}$ and, following iron-chelating treatment, has a hepatic iron of $36 \mathrm{mg} / \mathrm{g}$ liver, dw. Although hepatic iron has decreased by $10 \%$, application of accepted criteria would judge the chelator to be ineffective, because body iron persists at a level associated with an increased risk of cardiac disease and premature death, but application of the criteria judging "percentage changes" or "improving trends" would describe this therapy as effective. Finally, the reporting of "mean changes" in tissue or serum parameters of iron loading, in the absence of provision of individual patient responses, does not adequately inform the clinician or patient about the expectation for effectiveness for a given agent. As above, changes or lack of changes in ferritin values, although potentially useful in retrospective evaluation of body iron, may be misleading and should not be used to define effectiveness in individual patients.

\section{AGENTS USED FOR IRON CHELATION}

\section{Deferoxamine}

\section{Chemistry, Pharmacology, and Administration in Practice}

Deferoxamine is a hexadentate chelator that binds iron at a 1:1 molar ratio, rendering it virtually inactive metabolically. The drug is poorly absorbed orally (Callender and Weatherall 1980) and rapidly metabolized in plasma (Summers et al. 1979), conferring a requirement for prolonged parenteral infusions during which plasma concentrations reach a plateau at $12 \mathrm{~h}$. 
Deferoxamine is administered subcutaneously or intravenously, usually using a portable pump, for $8-10 \mathrm{~h} / \mathrm{d}, 5-7 \mathrm{~d} / \mathrm{wk}$ (Propper et al. 1977; Pippard et al. 1978). Subcutaneous administration is preferred except in patients with severe cardiac iron deposition for whom continuous intravenous deferoxamine therapy is recommended (Davis and Porter 2000). Oral ascorbic acid at the equivalent of 2$3 \mathrm{mg} / \mathrm{kg} / \mathrm{d}$ (Pippard et al. 1982) is usually prescribed at the beginning of an infusion.

\section{Clinical Benefits}

The evaluation of deferoxamine therapy antedates the common use of randomized, controlled trials (Brittenham 2011). For four decades following a randomized trial in which chronic intramuscular administration was shown to slow iron accumulation and arrest hepatic fibrosis in transfused patients (Barry et al. 1974), numerous observational studies provided evidence for deferoxamine-associated improvements in long-term survival related to improvements in cardiac disease. Cardiac disease even in transfused, nonchelated patients with thalassemia does not usually develop during the second decade of life, and if treatment with deferoxamine is available and supervised, it has become rare. Two trials of $>10-y$ duration confirmed unequivocally that long-term use of deferoxamine in thalassemia major is associated with long-term survival, free of the cardiac complications of iron overload (Brittenham et al. 1994; Olivieri et al. 1994). In one trial, patients with most serum ferritin concentrations $<2500 \mu \mathrm{g} / \mathrm{L}$ had an estimated cardiac-disease-free survival of $91 \%$ after 15 years, whereas cardiac-disease-free survival in those in whom most ferritins had exceeded $2500 \mu \mathrm{g} / \mathrm{L}$ was $<20 \%$ (Olivieri et al. 1994). The other trial classified patients as having received ineffective or effective chelation therapy using a threshold of body storage iron corresponding to a liver iron of $\sim 15 \mathrm{mg}$ iron/g liver, dw; the probability of survival to at least $25 \mathrm{yr}$ was only $32 \%$ among patients above this threshold, whereas no deaths occurred among patients below the threshold (Brittenham et al. 1994). A subsequent report involving more than 250 patients reported that those who administered deferoxamine at least 4.7 times/wk enjoyed 95\% survival at age 30 (Gabutti and Piga 1996). In the largest reported cohort in Italy, where deferoxamine was introduced in 1975, the prevalence of heart failure in patients aged $\geq 15 \mathrm{yr}$ decreased from $5 \%$ in patients born between 1970 and 1974 to 2\% in those born between 1980 and 1984 (BorgnaPignatti et al. 1998). A follow-up report identified one death from cardiac disease in the 19801984 birth cohort and no such deaths in subsequent birth cohorts (Borgna-Pignatti et al. 2004a). These findings show that accumulation of iron in heart is not inevitable, provided that body storage iron is controlled (Porter 2007). These North American and Italian data are paralleled in expert programs in the United Kingdom (Porter and Davis 2002), although poorer results are reported in centers in that country where erratic compliance and other impediments to effective treatment are likely less well managed (Modell et al. 2000). It would therefore appear that cardiac disease develops almost exclusively in thalassemia patients in whom effective treatment is unavailable, who begin deferoxamine after irreversible damage has occurred and/or who are not expertly supervised during long-term treatment.

The most common complication of iron loading in thalassemia, hypogonadism, is also prevented by effective use of deferoxamine (Bronspiegel-Weintrob et al. 1990), although secondary amenorrhea in women, and secondary hypogonadism in men, may develop after age 21 , even in those who have attained normal puberty (Gamberini et al. 2008).

\section{Tolerability and Toxicity of Deferoxamine}

Discomfort at the site of infusion may be mitigated with topical anesthetic or glucocorticoid creams (Brittenham 2011). Dose-related deferoxamine toxicities including visual changes, auditory toxicity, attenuation of linear growth, and skeletal dysplasia (Olivieri et al. 1986; Rodda et al. 1995; Chan et al. 2002; De Sanctis et al. 2006) may be minimized by maintaining doses of no more than $25-30 \mathrm{mg} / \mathrm{kg}$ in young 
children (Olivieri et al. 1992; Olivieri and Brittenham 1997). In both children and adults, as the hepatic iron concentration approaches optimal levels (see below), dose reduction is recommended; a useful recommendation is that the daily dose $(\mathrm{mg} / \mathrm{kg})$ divided by the serum ferritin (mg/L) should not exceed 0.025 (Porter and Huehns 1989; Porter et al. 1989). Allergy to deferoxamine is rare and most patients may be desensitized successfully (Porter 2001), with patients thereafter able to take deferoxamine. Monitoring of toxicity in patients who receive deferoxamine includes annual assessments of auditory function and vision and, in children, careful observations of linear growth including height velocity.

\section{Deferasirox}

\section{Chemistry, Pharmacology, and Administration} in Practice

The synthetic chelator deferasirox is a bis-hydroxyphenyl-triazole that, in contrast to deferoxamine, is well absorbed from the gastrointestinal tract and cleared from the circulation slowly with a plasma half-life of $11-19 \mathrm{~h}$, supporting once-daily oral dosing (Galanello et al. 2003; Nisbet-Brown et al. 2003; Waldmeier et al. 2010). Because of low water solubility of the free ligand, deferasirox is administered as a suspension in water or fruit juice (Novartis Pharmaceuticals 2010). Hepatocytes readily take up deferasirox, which chelates hepatocellular iron. Deferasirox-iron complexes are excreted in the bile (Waldmeier et al. 2010).

The short-term effectiveness of deferasirox has been compared with deferoxamine in trials sponsored by Novartis (Cappellini et al. 2006; Piga et al. 2006; Vichinsky et al. 2007; Porter et al. 2008; Cappellini et al. 2010). In the largest trial in which 586 children with thalassemia were randomly assigned to either agent, with dosing according to the baseline hepatic iron concentration (Cappellini et al. 2006), the primary end point was the percentage of patients with either a maintained or reduced hepatic iron concentration at $1 \mathrm{yr}$. This end point was reached in $52.9 \%$ of patients assigned to defer- asirox and in $66.4 \%$ of patients assigned to deferoxamine. This result, which did not meet a prespecified noninferiority target, was attributed to the relative underdosing of deferasirox (Brittenham 2011). No trial has established the long-term effectiveness of deferasirox in preventing organ toxicity or improving survival.

\section{Tolerability and Unwanted Effects of Deferasirox}

In the registration trial of deferasirox (Cappellini et al. 2006), gastrointestinal disturbances occurred in $\sim 15 \%$ of patients, rash in $11 \%$, and increases in serum creatinine levels in 38\%. Similar rates have been observed in subsequent trials (Piga et al. 2006; Vichinsky et al. 2007; Porter et al. 2008). In 2010, on the basis of postmarketing studies, the Food and Drug Administration required a change in the prescribing information for deferasirox, stating that the drug could cause potentially fatal renal and hepatic impairment or failure as well as gastrointestinal hemorrhage. These adverse effects were reported to occur more frequently in older patients and in patients with high-risk myelodysplastic syndromes, thrombocytopenia, or underlying renal or hepatic impairment. In patients who receive deferasirox, serum creatinine, serum aminotransferases, and bilirubin levels should be assessed monthly (Novartis Pharmaceuticals 2010).

\section{Deferiprone}

In both the European Union and the United States, the approved use of the synthetic oral iron-chelating agent deferiprone is restricted to patients with transfusional iron overload owing to thalassemia syndromes when current chelation therapy is inadequate. Deferiprone is not approved for use in Canada. Because this agent is not recommended for primary iron-chelating therapy, it is considered here only briefly.

\section{Chemistry, Pharmacology, and Administration in Practice \\ Deferiprone is a 3-hydroxypyridin-4-1 biden- tate chelator that binds to iron in a 3:1 ratio}


(Porter and Shah 2010). The drug has a plasma half-life of $1.5 \mathrm{~h}$ (Olivieri et al. 1990) and is usually given three times daily.

\section{Clinical Benefits}

In the United States, approval was based on a reduction in serum ferritin levels; sustained reduction in liver iron concentration during deferiprone treatment has not been shown. The FDA prescribing information states that there "are no controlled trials demonstrating a direct treatment benefit, such as improvement in disease-related symptoms, functioning, or increased survival" (Food and Drug Administration 2011).

\section{Tolerability and Unwanted Effects}

Common adverse effects include nausea, diarrhea, and arthropathy, including arthritis associated with clinically significant disability. The most serious adverse effects are agranulocytosis and neutropenia, increases in liver enzymes (Cohen et al. 2003), and progression of hepatic fibrosis associated with an increase in iron overload or hepatitis C. Weekly monitoring of the neutrophil count is recommended. Neurologic abnormalities have been reported during administration of higher-than-recommended doses (Beau-Salinas et al. 2009). In patients who receive deferiprone, weekly assessment of complete blood counts and monthly assessments of serum aminotransferases should be performed (European Medicines Agency 2009).

\section{Approach to Therapy}

An informed decision with respect to the choice of an iron chelator is best made with the patient or guardian. Despite the lack of data on longterm effectiveness, most patients now opt for deferasirox because of the ease of administration (Brittenham 2011). Patients, particularly those with severe iron overload with cardiac involvement, who are informed about the efficacy of deferoxamine in the reversal of iron-induced heart disease (Davis and Porter 2000) and improving long-term survival, may indicate a pref- erence for the proven therapy. Deferasirox may be substituted for deferoxamine when cardiac function is improved, or it could also be a choice in patients who are unable to tolerate infusions of deferoxamine (Brittenham 2011).

\section{Combination Therapy}

The long-term effectiveness of a variety of binary combinations of chelating agents presently administered in off-label uses remains uncertain due to the absence of unequivocal evidence of the superiority of any specific combination over treatment with a single agent (Roberts et al. 2007; Brittenham 2011).

\section{Monitoring}

The control of iron-chelating therapy is best implemented by periodic measurements of hepatic iron and of cardiac function. Serum ferritin concentrations are usually measured twice a year. On an annual basis, hepatic, cardiac, and endocrine function should be evaluated and, in children and adolescents, growth and sexual maturation formally assessed. Monitoring of toxicity will depend on the potential adverse effects of the specific agent to be used as above.

\section{Financial Costs of Iron-Chelating Therapy}

In North America (Vichinsky et al. 2005) and Europe (Modell et al.2001), the combined number of patients with transfusion-dependent thalassemia is $<10,000$. Globally, at least 100,000 patients with thalassemia require transfusions (Weatherall 2010). As previously discussed (Brittenham 2011), the annual per-patient costs of care for complications of iron overload are estimated to be $\$ 15,000-\$ 20,000$.

What is less well calculated, particularly in emerging countries, are costs associated with inadequate chelating therapy that may be collected from publications that report the costs in richer countries of failure of compliance with therapy (Delea et al. 2007). Full therapeutic doses of effective iron-chelating agents are affordable in only a minority of patients in countries worldwide, and regimens of treatment in 
these countries include the wider application of less effective drugs and combinations of drugs, or homeopathic doses of deferoxamine or deferasirox. As expected, heart and liver disease and endocrine dysfunction are, ultimately, not prevented by these regimens. The complications of iron overload that can be expected to develop result in increased costs in medical care, which, like chelating therapy itself, are generally borne primarily by the family of the individual in these countries. Unassisted by patient organizations that focus most efforts in North America and Europe, this situation is now being addressed through efforts by smaller charities.

\section{CONCLUSIONS}

Clearly, there have been major improvements in the symptomatic management of severe thalassemias, at least in the wealthier countries of the world. Although, as discussed by Weatherall (2010), owing to increasing international collaboration, at least some progress is also being made in the developing countries, but the situation is still far from satisfactory. As these countries go through the epidemiological transition resulting from improvements in public health, nutrition, and medical care, the number of babies who would previously have died before presenting for treatment with thalassemia is likely to decrease; hence, it is almost certain that overall, the number of patients with this condition will increase in the future. It may be some time before more radical forms of treatment such as gene therapy become available and, even then, they are likely to be very expensive. Hence, despite the increased development of public education, counseling, and prenatal diagnosis, it is likely that the symptomatic approach to the management of thalassemias, as outlined in this brief article, will remain of considerable importance for the foreseeable future.

\section{REFERENCES}

* Reference is also in this collection.

Allen A, Fisher C, Premawardhena A, Peto T, Allen S, Arambepola M, Thayalsutha V, Olivieri N, Weatherall D.
2010. Adaptation to anemia in hemoglobin E-ss thalassemia. Blood 116: 5368-5370.

Anderson LJ, Holden S, Davis B, Prescott E, Charrier CC, Bunce NH, Firmin DN, Wonke B, Porter J, Walker JM, et al. 2001. Cardiovascular T2-star (T2*) magnetic resonance for the early diagnosis of myocardial iron overload. Eur Heart J 22: 2171-2179.

Anderson LJ, Wonke B, Prescott E, Holden S, Walker JM, Pennell DJ. 2002. Comparison of effects of oral deferiprone and subcutaneous desferrioxamine on myocardial iron concentrations and ventricular function in $\beta$-thalassaemia. Lancet 360: 516-520.

Anderson LJ, Westwood MA, Prescott E, Walker JM, Pennell DJ, Wonke B. 2006. Development of thalassaemic iron overload cardiomyopathy despite low liver iron levels and meticulous compliance to desferrioxamine. Acta Haematol 115: 106-108.

Angelucci E, Brittenham GM, McLaren CE, Ripalti M, Baronciani D, Giardini C, Galimberti M, Polchi P, Lucarelli G. 2000. Hepatic iron concentration and total body iron stores in thalassemia major. $N$ Engl J Med 343: 327-331.

Angelucci E, Muretto P, Nicolucci A, Baronciani D, Erer B, Gaziev J, Ripalti M, Sodani P, Tomassoni S, Visani G, et al. 2002. Effects of iron overload and hepatitis $C$ virus positivity in determining progression of liver fibrosis in thalassemia following bone marrow transplantation. Blood 100: $17-21$.

Argyropoulou MI, Kiortsis DN, Efremidis SC. 2003. MRI of the liver and the pituitary gland in patients with $\beta$-thalassemia major: Does hepatic siderosis predict pituitary iron deposition? Eur Radiol 13: 12-16.

* Arora N, Daley GQ. 2012. Pluripotent stem cells in research and treatment of hemoglobinopathies. Cold Spring Harb Perpect Med 2: a011841.

Au WY, Lam WW, Chu W, Tam S, Wong WK, Liang R, Ha SY 2008a. A T2* magnetic resonance imaging study of pancreatic iron overload in thalassemia major. Haematologica 93: 116-119.

Au WY, Lam WW, Chu WW, Yuen HL, Ling AS, Li RC, Chan HM, Lee HK, Law MF, Liu HS, et al. 2008b. A cross-sectional magnetic resonance imaging assessment of organ specific hemosiderosis in 180 thalassemia major patients in Hong Kong. Haematologica 93: 784-786.

Barry M, Flynn DM, Letsky EA, Risdon RA. 1974. Longterm chelation therapy in thalassaemia major: Effect on liver iron concentration, liver histology, and clinical progress. Br Med J 2: 16-20.

Beau-Salinas F, Guitteny MA, Donadieu J, Jonville-Bera AP, Autret-Leca E. 2009. High doses of deferiprone may be associated with cerebellar syndrome. BMJ 338: a2319.

Bergeron C, Kovacs K. 1978. Pituitary siderosis. A histologic, immunocytologic, and ultrastructural study. Am J Pathol 93: 295-309.

Borgna-Pignatti C, Rugolotto S, De Stefano P, Piga A, Di Gregorio F, Gamberini MR, Sabato V, Melevendi C, Cappellini MD, Verlato G. 1998. Survival and disease complications in thalassemia major. Ann NY Acad Sci 850: $227-231$.

Borgna-Pignatti C, Rugolotto S, De Stefano P, Zhao H, Cappellini MD, Del Vecchio GC, Romeo MA, Forni GL, Gamberini MR, Ghilardi R, et al. 2004a. Survival and 
N.F. Olivieri and G.M. Brittenham

complications in patients with thalassemia major treated with transfusion and deferoxamine. Haematologica 89: 1187-1193.

Borgna-Pignatti C, Vergine G, Lombardo T, Cappellini MD, Cianciulli P, Maggio A, Renda D, Lai ME, Mandas A, Forni G, et al. 2004b. Hepatocellular carcinoma in the thalassaemia syndromes. Br J Haematol 124: 114-117.

Breuer W, Hershko C, Cabantchik ZI. 2000. The importance of non-transferrin bound iron in disorders of iron metabolism. Transfus Sci 23: 185-192.

Brittenham GM. 2011. Iron-chelating therapy for transfusional iron overload. $N$ Engl J Med 364: 146-156.

Brittenham GM, Farrell DE, Harris JW, Feldman ES, Danish EH, Muir WA, Tripp JH, Bellon EM. 1982. Magnetic-susceptibility measurement of human iron stores. N Engl J Med 307: 1671-1675.

Brittenham GM, Cohen AR, McLaren CE, Martin MB, Griffith PM, Nienhuis AW, Young NS, Allen CJ, Farrell DE, Harris JW. 1993. Hepatic iron stores and plasma ferritin concentration in patients with sickle cell anemia and thalassemia major. Am J Hematol 42: 81-85.

Brittenham GM, Griffith PM, Nienhuis AW, McLaren CE, Young NS, Tucker EE, Allen CJ, Farrell DE, Harris JW. 1994. Efficacy of deferoxamine in preventing complications of iron overload in patients with thalassemia major. N Engl J Med 331: 567-573.

Bronspiegel-Weintrob N, Olivieri NF, Tyler B, Andrews DF, Freedman MH, Holland FJ. 1990. Effect of age at the start of iron chelation therapy on gonadal function in $\beta$-thalassemia major. $N$ Engl J Med 323: 713-719.

Callender ST, Weatherall DJ. 1980. Iron chelation with oral desferrioxamine. Lancet 316: 689.

* Cao A, Kan YW. 2013. The prevention of thalassemia. Cold Spring Harb Perpect Med 3: a011775.

Cappellini MD, Cohen A, Piga A, Bejaoui M, Perrotta S, Agaoglu L, Aydinok Y, Kattamis A, Kilinc Y, Porter J, et al. 2006. A phase 3 study of deferasirox (ICL670), a oncedaily oral iron chelator, in patients with $\beta$-thalassemia. Blood 107: 3455-3462.

Cappellini MD, Porter J, El-Beshlawy A, Li CK, Seymour JF, Elalfy M, Gattermann N, Giraudier S, Lee JW, Chan LL, et al. 2010. Tailoring iron chelation by iron intake and serum ferritin: The prospective EPIC study of deferasirox in 1744 patients with transfusion-dependent anemias. Haematologica 95: 557-566.

Cartwright GE, Edwards CQ, Kravitz K, Skolnick M, Amos DB, Johnson A, Buskjaer L. 1979. Hereditary hemochromatosis. Phenotypic expression of the disease. $N$ Engl J Med 301: 175-179.

Cazzola M, Borgna-Pignatti C, Locatelli F, Ponchio L, Beguin Y, De Stefano P. 1997. A moderate transfusion regimen may reduce iron loading in $\beta$-thalassemia major without producing excessive expansion of erythropoiesis. Transfusion 37: 135-140.

Chan YL, Pang LM, Chik KW, Cheng JC, Li CK. 2002. Patterns of bone diseases in transfusion-dependent homozygous thalassaemia major: Predominance of osteoporosis and desferrioxamine-induced bone dysplasia. Pediatr Radiol 32: 492-497.

Chatterjee R, Katz M, Oatridge A, Bydder GM, Porter JB. 1998. Selective loss of anterior pituitary volume with severe pituitary-gonadal insufficiency in poorly compliant male thalassemic patients with pubertal arrest. Ann NY Acad Sci 850: 479-482.

Christoforidis A, Haritandi A, Perifanis V, Tsatra I, Athanassiou-Metaxa M, Dimitriadis AS. 2007. MRI for the determination of pituitary iron overload in children and young adults with $\beta$-thalassaemia major. Eur J Radiol 62: $138-142$.

Cohen AR, Galanello R, Piga A, De Sanctis V, Tricta F. 2003. Safety and effectiveness of long-term therapy with the oral iron chelator deferiprone. Blood 102: 1583-1587.

Cohen AR, Glimm E, Porter JB. 2008. Effect of transfusional iron intake on response to chelation therapy in $\beta$-thalassemia major. Blood 111: 583-587.

Davis BA, Porter JB. 2000. Long-term outcome of continuous 24-hour deferoxamine infusion via indwelling intravenous catheters in high-risk $\beta$-thalassemia. Blood 95: $1229-1236$.

Davis BA, O'Sullivan C, Jarritt PH, Porter JB. 2004. Value of sequential monitoring of left ventricular ejection fraction in the management of thalassemia major. Blood 104: 263-269.

Delea TE, Edelsberg J, Sofrygin O, Thomas SK, Baladi JF, Phatak PD, Coates TD. 2007. Consequences and costs of noncompliance with iron chelation therapy in patients with transfusion-dependent thalassemia: A literature review. Transfusion 47: 1919-1929.

De Sanctis V, Roos M, Gasser T, Fortini M, Raiola G, Galati MC. 2006. Impact of long-term iron chelation therapy on growth and endocrine functions in thalassemia. J Pediatr Endocrinol Metab 19: 471-480.

European Medicines Agency. 2009. Ferriprox (deferiprone): Summary of product characteristics. European Public Assessment Report, rev. ed. 14 (http://wwwemaeuropaeu/ humandocs/Humans/EPAR/ferriprox/ferriproxhtm).

Farmaki K, Tzoumari I, Pappa C, Chouliaras G, Berdoukas V. 2010. Normalisation of total body iron load with very intensive combined chelation reverses cardiac and endocrine complications of thalassaemia major. Br J Haematol 148: $466-475$.

Food and Drug Administration. 2011. Briefing document for the Oncologic Drugs Advisory Committee Meeting, September 14 (http://www.fda.gov/downloads/AdvisoryCommittees/CommitteesMeetingMaterials/Drugs/OncologicDrugsAdvisoryCommittee/UCM271537.pdf).

Fujisawa I, Morikawa M, Nakano Y, Konishi J. 1988. Hemochromatosis of the pituitary gland: MR imaging. Radiology 168: 213-214.

Gabutti V, Piga A. 1996. Results of long-term iron-chelating therapy. Acta Haematol 95: 26-36.

Galanello R, Piga A, Alberti D, Rouan MC, Bigler H, Sechaud R. 2003. Safety, tolerability, and pharmacokinetics of ICL670, a new orally active iron-chelating agent in patients with transfusion-dependent iron overload due to $\beta$-thalassemia. J Clin Pharmacol 43: 565-572.

Gamberini MR, De Sanctis V, Gilli G. 2008. Hypogonadism, diabetes mellitus, hypothyroidism, hypoparathyroidism: Incidence and prevalence related to iron overload and chelation therapy in patients with thalassaemia major followed from 1980 to 2007 in the Ferrara Centre. Pediatr Endocrinol Rev 6: 158-169. 
Garbowski M, Eleftheriou P, Pennell D Tanner M Porter JB. 2008. Impact of compliance, ferritin and LIC on longterm trends in myocardial T2* with deferasirox. Blood 112: 116 .

Higgs DR. 2009. The pathophysiology and clinical features of a thalassemia. In Disorders of hemoglobin (ed. Steinberg MH, Forget BG, Higgs DR, Weatherall DJ), pp. 266-295. Cambridge University Press, Cambridge.

Iancu TC, Neustein HB. 1977. Ferritin in human liver cells of homozygous $\beta$-thalassaemia: Ultrastructural observations. Br J Haematol 37: 527-535.

Jacobs EM, Hendriks JC, van Tits BL, Evans PJ, Breuer W, Liu DY, Jansen EH, Jauhiainen K, Sturm B, Porter JB, et al. 2005. Results of an international round robin for the quantification of serum non-transferrin-bound iron: Need for defining standardization and a clinically relevant isoform. Anal Biochem 341: 241-250.

Jensen PD, Jensen FT, Christensen T, Eiskjaer H, Baandrup U, Nielsen JL. 2003. Evaluation of myocardial iron by magnetic resonance imaging during iron chelation therapy with deferrioxamine: Indication of close relation between myocardial iron content and chelatable iron pool. Blood 101: 4632-4639.

Kirk P, Roughton M, Porter JB, Walker JM, Tanner MA, Patel J, Wu D, Taylor J, Westwood MA, Anderson LJ, et al. 2009. Cardiac T2* magnetic resonance for prediction of cardiac complications in thalassemia major. Circulation 120: 1961-1968.

Ko C, Siddaiah N, Berger J, Gish R, Brandhagen D, Sterling RK, Cotler SJ, Fontana RJ, McCashland TM, Han SH, et al. 2007. Prevalence of hepatic iron overload and association with hepatocellular cancer in end-stage liver disease: Results from the National Hemochromatosis Transplant Registry. Liver Int 27: 1394-1401.

* Lucarelli G, Isgrò A, Sodani P, Gaziev J. 2012. Hematopoietic stem cell transplantation in thalassemia and sickle cell anemia. Cold Spring Harb Perpect Med 2: a011825.

Midiri M, Lo Casto A, Sparacia G, D’Angelo P, Malizia R, Finazzo M, Montalto G, Solbiati L, Lagalla R, De Maria M. 1999. MR imaging of pancreatic changes in patients with transfusion-dependent $\beta$-thalassemia major. AJR Am J Roentgenol 173: 187-192.

Modell B, Khan M, Darlison M. 2000. Survival in $\beta$-thalassaemia major in the UK: Data from the UK Thalassaemia Register. Lancet 355: 2051-2052.

Modell B, Khan M, Darlison M, King A, Layton M, Old J, Petrou M, Varnavides L. 2001. A national register for surveillance of inherited disorders: $\beta$-Thalassaemia in the United Kingdom. Bull World Health Org 79: 1006-1013

Musallam KM, Cappellini MD, Wood JC, Motta I, Graziadei G, Tamim H, Taher AT. 2011. Elevated liver iron concentration is a marker of increased morbidity in patients with $\beta$ thalassemia intermedia. Haematologica 96: $1605-1612$.

* Nienhuis AW, Persons DA. 2012. Development of gene therapy for thalassemia. Cold Spring Harb Perpect Med 2: a011833.

Nisbet-Brown E, Olivieri NF, Giardina PJ, Grady RW, Neufeld EJ, Sechaud R, Krebs-Brown AJ, Anderson JR, Alberti D, Sizer KC, et al. 2003. Effectiveness and safety of ICL670 in iron-loaded patients with thalassaemia: A randomised, double-blind, placebo-controlled, dose-escalation trial. Lancet 361: 1597-1602.

Noetzli LJ, Carson SM, Nord AS, Coates TD, Wood JC. 2008. Longitudinal analysis of heart and liver iron in thalassemia major. Blood 112: 2973-2978.

Noetzli LJ, Papudesi J, Coates TD, Wood JC. 2009. Pancreatic iron loading predicts cardiac iron loading in thalassemia major. Blood 114: 4021-4026.

Noetzli LJ, Mittelman SD, Watanabe RM, Coates TD, Wood JC. 2011a. Pancreatic iron and glucose dysregulation in thalassemia major. Am J Hematol doi: 10.1002/ ajh.22223.

Noetzli LJ, Panigrahy A, Mittelman SD, Hyderi A, Dongelyan A, Coates TD, Wood JC. 2011b. Pituitary iron and volume predict hypogonadism in transfusional iron overload. Am J Hematol doi: 10.1002/ajh.22247.

Novartis Pharmaceuticals. 2010. Exjade (deferasirox) prescribing information (http://www.exjade.com).

Olivieri NF, Brittenham GM. 1997. Iron-chelating therapy and the treatment of thalassemia. Blood 89: 739-761.

Olivieri NF, Weatherall DJ. 2009. Clinical aspects of $\beta$ thalassemia and related disorders. In Disorders of hemoglobin (ed. Steinberg MH, Forget BG, Higgs DR, Weatherall DJ), pp. 357-416. Cambridge University Press, Cambridge.

Olivieri NF, Buncic JR, Chew E, Gallant T, Harrison RV, Keenan N, Logan W, Mitchell D, Ricci G, Skarf B, et al. 1986. Visual and auditory neurotoxicity in patients receiving subcutaneous deferoxamine infusions. $N$ Engl J Med 314: 869-873.

Olivieri NF, Koren G, Hermann C, Bentur Y, Chung D, Klein J, St Louis P, Freedman MH, McClelland RA, Templeton DM. 1990. Comparison of oral iron chelator $\mathrm{L} 1$ and desferrioxamine in iron-loaded patients. Lancet 336: $1275-1279$.

Olivieri NF, Koren G, Harris J, Khattak S, Freedman MH, Templeton DM, Bailey JD, Reilly BJ. 1992. Growth failure and bony changes induced by deferoxamine. Am J Pediatr Hematol Oncol 14: 48-56.

Olivieri NF, Nathan DG, MacMillan JH, Wayne AS, Liu PP, McGee A, Martin M, Koren G, Cohen AR. 1994. Survival in medically treated patients with homozygous $\beta$-thalassemia. N Engl J Med 331: 574-578.

Olivieri NF, Brittenham GM, Matsui D, Berkovitch M, Blendis LM, Cameron RG, McClelland RA, Liu PP, Templeton DM, Koren G. 1995. Iron-chelation therapy with oral deferipronein patients with thalassemia major. N Engl J Med 332: 918-922.

Pennell DJ, Berdoukas V, Karagiorga M, Ladis V, Piga A, Aessopos A, Gotsis ED, Tanner MA, Smith GC, Westwood MA, et al. 2006. Randomized controlled trial of deferiprone or deferoxamine in $\beta$-thalassemia major patients with asymptomatic myocardial siderosis. Blood 107: $3738-3744$

Piga A, Galanello R, Forni GL, Cappellini MD, Origa R, Zappu A, Donato G, Bordone E, Lavagetto A, Zanabon L, et al. 2006. Randomized phase II trial of deferasirox (Exjade, ICL670), a once-daily, orally-administered iron chelator, in comparison to deferoxamine in thalassemia patients with transfusional iron overload. Haematologica 91: 873-880. 
N.F. Olivieri and G.M. Brittenham

Pippard MJ, Weatherall DJ. 1984. Iron absorption in nontransfused iron loading anaemias: Prediction of risk for iron loading, and response to iron chelation treatment, in $\beta$ thalassaemia intermedia and congenital sideroblastic anaemias. Haematologia (Budap) 17: 17-24.

Pippard MJ, Letsky EA, Callender ST, Weatherall DJ. 1978. Prevention of iron loading in transfusion-dependent thalassaemia. Lancet 1: 1178-1181.

Pippard MJ, Callender ST, Warner GT, Weatherall DJ. 1979. Iron absorption and loading in $\beta$-thalassaemia intermedia. Lancet 2: 819-821.

Pippard MJ, Callender ST, Finch CA. 1982. Ferrioxamine excretion in iron-loaded man. Blood 60: 288-294.

Porter JB. 2001. Practical management of iron overload. Br J Haematol 115: 239-252.

Porter JB. 2007. Concepts and goals in the management of transfusional iron overload. Am J Hematol 82: 11361139.

Porter JB, Davis BA. 2002. Monitoring chelation therapy to achieve optimal outcome in the treatment of thalassaemia. Best Pract Res Clin Haematol 15: 329-368.

Porter JB, Huehns ER. 1989. The toxic effects of desferrioxamine. Baillieres Clin Haematol 2: 459-474.

Porter JB, Shah FT. 2010. Iron overload in thalassemia and related conditions: Therapeutic goals and assessment of response to chelation therapies. Hematol Oncol Clin North Am 24: 1109-1130.

Porter JB, Jaswon MS, Huehns ER, East CA, Hazell JW. 1989. Desferrioxamine ototoxicity: Evaluation of risk factors in thalassaemic patients and guidelines for safe dosage. $\mathrm{Br} J$ Haematol 73: 403-409.

Porter J, Galanello R, Saglio G, Neufeld EJ, Vichinsky E, Cappellini MD, Olivieri N, Piga A, Cunningham MJ, Soulieres D, et al. 2008. Relative response of patients with myelodysplastic syndromes and other transfusiondependent anaemias to deferasirox (ICL670): A 1-yr prospective study. Eur J Haematol 80: 168-176.

Prieto J, Barry M, Sherlock S. 1975. Serum ferritin in patients with iron overload and with acute and chronic liver diseases. Gastroenterology 68: 525-533.

Propper RD, Cooper B, Rufo RR, Nienhuis AW, Anderson WF, Bunn HF, Rosenthal A, Nathan DG. 1977. Continuous subcutaenous administration of deferoxamine in patients with iron overload. N Engl J Med 297: 418-423.

Rebulla P, Modell B. 1991. Transfusion requirements and effects in patients with thalassaemia major. Cooleycare Programme. Lancet 337: 277-280.

Roberts DJ, Brunskill SJ, Doree C, Williams S, Howard J, Hyde CJ. 2007. Oral deferiprone for iron chelation in people with thalassaemia. Cochrane Database Syst Rev No. 3: CD004839.

Rodda CP, Reid ED, Johnson S, Doery J, Matthews R, Bowden DK. 1995. Short stature in homozygous $\beta$-thalassaemia is due to disproportionate truncal shortening. Clin Endocrinol (Oxf) 42: 587-592.

Saxon B, Brittenham G, Nisbet-Brown E, Chait P, Klein N, Muraca M, Olivieri N. 1997. Liver biopsy is safe and provides quantitative guidelines for initiation of chelating therapy in children with thalassemia major. Blood $\mathbf{9 0}$ : 130a.

St Pierre TG, Clark PR, Chua-anusorn W, Fleming AJ, Jeffrey GP, Olynyk JK, Pootrakul P, Robins E, Lindeman R. 2005. Noninvasive measurement and imaging of liver iron concentrations using proton magnetic resonance. Blood 105: 855-861.

Summers MR, Jacobs A, Tudway D, Perera P, Ricketts C. 1979. Studies in desferrioxamine and ferrioxamine metabolism in normal and iron-loaded subjects. $\mathrm{Br} \mathrm{J} \mathrm{Hae-}$ matol 42: 547-555.

Taher AT, Musallam KM, Cappellini MD, Weatherall DJ. 2011. Optimal management of $\beta$ thalassaemia intermedia. Br J Haematol 152: 512-523.

Taher AT, Musallam KM, Karimi M, Cappellini MD. 2012. Contemporary approaches to treatment of $\beta$-thalassemia intermedia. Blood Rev 26: S24-S27.

Tanner MA, Galanello R, Dessi C, Smith GC, Westwood MA, Agus A, Pibiri M, Nair SV, Walker JM, Pennell DJ. 2008. Combined chelation therapy in thalassemia major for the treatment of severe myocardial siderosis with left ventricular dysfunction. J Cardiovasc Magn Reson 10: 12.

Telfer PT, Prestcott E, Holden S, Walker M, Hoffbrand AV, Wonke B. 2000. Hepatic iron concentration combined with long-term monitoring of serum ferritin to predict complications of iron overload in thalassaemia major. $\mathrm{Br}$ J Haematol 110: 971-977.

Vichinsky EP, MacKlin EA, Waye JS, Lorey F, Olivieri NF. 2005. Changes in the epidemiology of thalassemia in North America: A new minority disease. Pediatrics 116: e818-e825.

Vichinsky E, Onyekwere O, Porter J, Swerdlow P, Eckman J, Lane P, Files B, Hassell K, Kelly P, Wilson F, et al. 2007. A randomised comparison of deferasirox versus deferoxamine for the treatment of transfusional iron overload in sickle cell disease. Br J Haematol 136: 501-508.

Waldmeier F, Bruin GJ, Glaenzel U, Hazell K, Sechaud R, Warrington S, Porter JB. 2010. Pharmacokinetics, metabolism, and disposition of deferasirox in $\beta$-thalassemic patients with transfusion-dependent iron overload who are at pharmacokinetic steady state. Drug Metab Dispos 38: $808-816$.

Weatherall DJ. 2010. The inherited diseases of hemoglobin are an emerging global health burden. Blood 115: 43314336 .

Weatherall D, Clegg JB. 2001. The thalassemia syndromes. Blackwell Science, Oxford, England.

Worwood M, Cragg SJ, Jacobs A, McLaren C, Ricketts C, Economidou J. 1980. Binding of serum ferritin to concanavalin A: Patients with homozygous $\beta$ thalassaemia and transfusional iron overload. Br J Haematol 46: 409416.

Zurlo MG, De Stefano P, Borgna-Pignatti C, Di Palma A, Piga A, Melevendi C, Di Gregorio F, Burattini MG, Terzoli S. 1989. Survival and causes of death in thalassaemia major. Lancet 2: 27-30. 


\section{$\&_{\mathrm{CSH}}^{\infty} \&$ Cold Spring Harbor

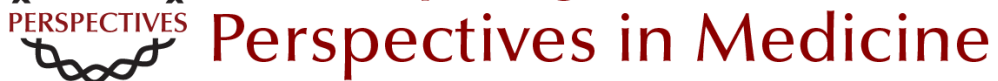

\section{Management of the Thalassemias}

Nancy F. Olivieri and Gary M. Brittenham

Cold Spring Harb Perspect Med 2013; doi: 10.1101/cshperspect.a011767

Subject Collection Hemoglobin and Its Diseases

The Natural History of Sickle Cell Disease Graham R. Serjeant

Current Management of Sickle Cell Anemia Patrick T. McGann, Alecia C. Nero and Russell E. Ware

Cell-Free Hemoglobin and Its Scavenger Proteins: New Disease Models Leading the Way to Targeted Therapies Dominik J. Schaer and Paul W. Buehler

Clinical Manifestations of $\alpha$-Thalassemia Elliott P. Vichinsky

Erythroid Heme Biosynthesis and Its Disorders Harry A. Dailey and Peter N. Meissner

Hemoglobin Variants: Biochemical Properties and

Clinical Correlates Christopher S. Thom, Claire F. Dickson, David A. Gell, et al.

The Prevention of Thalassemia Antonio Cao and Yuet Wai Kan

The Switch from Fetal to Adult Hemoglobin Vijay G. Sankaran and Stuart H. Orkin
Transcriptional Mechanisms Underlying

Hemoglobin Synthesis

Koichi R. Katsumura, Andrew W. DeVilbiss, Nathaniel J. Pope, et al.

Iron Deficiency Anemia: A Common and Curable Disease Jeffery L. Miller

Management of the Thalassemias Nancy F. Olivieri and Gary M. Brittenham

The Molecular Basis of $\beta$-Thalassemia Swee Lay Thein

Erythropoiesis: Development and Differentiation Elaine Dzierzak and Sjaak Philipsen

Erythropoietin

H. Franklin Bunn

Classification of the Disorders of Hemoglobin Bernard G. Forget and H. Franklin Bunn

The Molecular Basis of $\alpha$-Thalassemia Douglas R. Higgs

For additional articles in this collection, see http://perspectivesinmedicine.cshlp.org/cgi/collection/ 